1983

\title{
The Ambiguity of Equity in International Law
}

Mark Weston Janis

University of Connecticut School of Law

Follow this and additional works at: https://opencommons.uconn.edu/law_papers

Part of the International Law Commons

\section{Recommended Citation}

Janis, Mark Weston, "The Ambiguity of Equity in International Law" (1983). Faculty Articles and Papers. 407.

https://opencommons.uconn.edu/law_papers/407 


\section{HEINONLINE}

Citation:

M. W. Janis, The Ambiguity of Equity in International

Law, 9 Brook. J. Int'l L. 7 (1983)

Content downloaded/printed from $\underline{\text { HeinOnline }}$

Mon May 13 10:21:50 2019

-- Your use of this HeinOnline PDF indicates your

acceptance of HeinOnline's Terms and Conditions

of the license agreement available at

https://heinonline.org/HOL/License

-- The search text of this PDF is generated from uncorrected OCR text.

-- To obtain permission to use this article beyond the scope of your HeinOnline license, please use:

\section{Copyright Information}

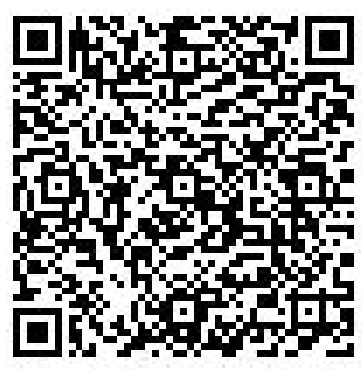

Use QR Code reader to send PDF to your smartphone or tablet device 


\title{
THE AMBIGUITY OF EQUITY IN INTERNATIONAL LAW
}

\author{
M. W. Janis*
}

INTRODUCTION

International law is sometimes interpreted differently by international lawyers representing different national, societal and doctrinal traditions. Thus, there is often a more difficult problem of understanding and explaining even apparently simple usages in international law than is sometimes appreciated. For example, the notion of equity in international law is subject to such different interpretations that an analysis of the concept may serve as a warning of how dangerous it is to assume that language in international law necessarily has a single or settled meaning.

The work below is, first, descriptive: to explain some prevalent doctrinal perceptions of the role of equity in international law; second, analytical: to evaluate how well or poorly such doctrine works in explaining recent international practice; and, third, prescriptive: to elaborate a third perception of the role of equity in international law that may help both to bridge some of the gaps in theory and to facilitate a clearer and more consistent understanding of what equity means in practice. Finally, a few concluding comments consider the larger problem of understanding international law from differing perspectives.

\section{Equity and the Western Doctrinal Tradition}

The first doctrinal perception of equity is that of Western international lawyers in the Anglo-American and civil law tradition. To a considerable extent, this perception is rooted in Aristotle, who defined equity as follows:

[T] he equitable is not just in the legal sense of "just" but as a

* Associate Professor of Law, University of Connecticut School of Law; Visiting Associate Professor of Law, Cornell Law School, Spring 1983. Princeton University, A.B. 1969; Oxford University, B.A. 1972, M.A. 1975; Harvard Law School, J.D. 1977. Member New York Bar.

The author is indebted to Professor Louis Sohn for his encouragement on and insights into this and other projects, and to Professors Thomas Morawetz, Alfred Rubin, Henry Steiner and Nicholas Wolfson for their very helpful comments on an earlier draft of this paper. 
corrective of what is legally just. The reason is that all law is universal, but there are some things about which it is not possible to speak correctly in universal terms. Now, in situations where it is necessary to speak in universal terms but impossible to do so correctly, the law takes the majority of cases, fully realizing in what respect it misses the mark. The law itself is none the less correct. For the mistake lies neither in the law nor in the lawgiver, but in the nature of the case. For such is the material of which actions are made. So in a situation in which the law speaks universally, but the case at issue happens to fall outside the universal formula, it is correct to rectify the shortcoming, in other words, the omission and mistake of the lawgiver due to the generality of his statement. Such a rectification corresponds to what the lawgiver himself would have enacted if he had known [of this particular case]. That is why the equitable is both just and also better than the just in one sense. It is not better than the just in general, but better than the mistake due to the generality [of the law]. And this is the very nature of the equitable, a rectification of law where law falls short by reason of its universality. ${ }^{1}$

Beginning, at least, with Grotius' seminal treatise on international law in 1625, Western international lawyers have generally adopted Aristotle's view that equity is a discretionary corrective (applied in a specific case) of a strict universal law:

In judging of the will by natural reason, Aristotle, who has treated the subject with great accuracy, makes the mind the seat of judgment and the will the seat of equity, which he nobly defines to be the correction of that, wherein the law, by reason of its universal nature is defective.

And upon this principle all wills and treaties ought to be interpreted. For as all cases could neither be foreseen nor expressed by the lawgiver, it is necessary to leave a power of excepting the cases, which he himself would have excepted if he were present. ${ }^{2}$

The basic discretionary justice theory, of course, has been much elaborated and refined. Before very recent time, equity received most doctrinal attention in the 1930's, a time when Western international lawyers had high hopes for the prospects of in-

1. ARistotle, Nichomachean Ethics, bk. 5, ch. 10, 141-42 (Ostwald trans. 1962) [hereinafter cited as ARISTOTLE].

2. H. Grotius, The Rights of War and Peace, bk. 2, ch. 16, § 26, 190 (Campbell trans. 1901). 
ternational adjudication and international arbitration as effective and widespread means of dispute settlement. There was considerable thinking then about the extent to which international judges and arbiters had or should have discretion to apply equitable considerations particular to the specific case and, thus, to relax or supplement more or less strict rules of international law. ${ }^{3}$

This Western tradition, as elaborated in its peak period in the 1930s and as refined at greater leisure in the three decades thereafter, ${ }^{4}$ makes at least two important distinctions. Both distinctions are tools in constructing an equity theory that can explain when an international judge or arbiter would or should correct the law with equity.

The first distinction of traditional doctrine considers the difference between "equitable principles" and "ex aequo et bono." In a way, the distinction was forced on the international lawyers by the terms of article 38 of the Statute of the Permanent Court of International Justice (hereinafter referred to as P.C.I.J.) in 1920 and its successor, the International Court of Justice (hereinafter referred to as I.C.J.) in $1946 .^{6}$ Article 38(2)

3. See, e.g., Strupp, Le droit du juge international de statuer selon l'équité, 33 Hague Acadeny, RecueIL des Cours 351 (1930); Orfield, Equity as a Concept of International Law (pts. 1 \& 2), 18 Ky. L.J. 31, 116 (1929-1930); Mouskhéli, L'équité en droit international moderne, 40 REVUE GENERALE DE DROIT INTERNATIONAL PUBLIC 347 (1933); Aufricht, Equity-Maximen und Allgemeine Rechtsgrundsätze, 5 InTERNATIONALEs ANWALTSBLATT 118 (1934); Habicht, Le pouvoir du juge international de statuer " $E x$ aequo et bono," 49 HAGUE ACADEMY, REcuEIL DEs CouRs 277 (1934); N. BENTwich, A. De Bustamente, D. Maclean, G. Radbruch \& H. SMith, Justice and EQUity in the InTERNational Sphere (New Commonwealth Institute Monograph, Ser. B, No. 1, 1935); Jenks, Equity as a Part of the Law Applied by the Permanent Court of International Justice,

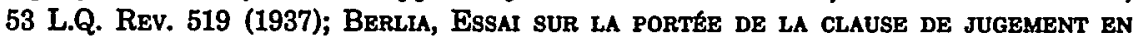
EQUITE EN DROIT DES GENS (1937).

4. See, e.g., Cheng, Justice and Equity in International Law, 8 CURRENT LEgal Probs. 185 (1955); Scheuner, Decisions Ex Aequo Et Bono by International Courts and Arbitral Tribunals, in INTERnational Arbitration LIBER Amicorum ror Martin Domke 275 (Sanders ed. 1967); Sohn, Arbitration of International Disputes Ex Aequo Et Bono, in id. at 330 [hereinafter cited as Sohn].

5. By what is equal and good. All translations are by the author.

6. Article 38 presently reads:

1. The Court, whose function is to decide in accordance with international law such disputes as are submitted to it, shall apply:

(a) international conventions, whether general or particular, establish-

ing rules expressly recognized by the contesting States;

(b) international custom, as evidence of a general practice accepted as

law;

(c) the general principles of law recognized by civilized nations;

(d) subject to the provisions of Article 59, judicial decisions and the 
made clear that decisions ex aequo et bono were only to be given if the parties consented and, since the 1946 revision, implied that these were not decisions given "in accordance with international law" like those in article 38(1). Since parties have never given the P.C.I.J. or the I.C.J. an ex aequo et bono authorization, and since article 38 has taken on an importance as a description of the "sources" of international law even outside the confines of the World Court, international lawyers have sought to find some way to include at least some equitable powers within the normal confines of international law. They have done so by distinguishing "equitable principles" that could be viewed as being incorporated into international law á la article $38(1)$ (c), which refers to "the general principles of law recognized by civilized nations" from the power to decide a case ex aequo et bono, which was sometimes described as an absolute grant of discretion to a judge to act as a legislator. ${ }^{8}$

Perhaps the most famous illustration of this use of equitable principles, as distinguished from the ex aequo et bono power of article 38(2), was in the individual opinion of Judge Manley O. Hudson in the 1937 P.C.I.J. case, The Diversion of Water from the Meuse. ${ }^{9}$ In this dispute, the Netherlands complained that Belgium was diverting water from the river Meuse in violation of a treaty entered into between the two countries. Judge Hudson, after finding that the Dutch were themselves similarly diverting water, asked:

[I]s this a case in which affirmative relief should be given by the Court? Or should it be said, in the terms of the alternative Belgian submission, that the Netherlands has in some measure

teachings of the most highly qualified publicists of the various nations, as subsidiary means for the determination of rules of law.

2. This provision shall not prejudice the power of the Court to decide a case ex aequo et bono, if the parties agree thereto.

The predecessor of the International Court of Justice [hereinafter referred to as I.C.J.], the Permanent Court of International Justice (1920-1946) [hereinafter referred to as P.C.I.J.] had a mandate identical to that in the I.C.J.'s Article 38, except that the P.C.I.J.'s Article 38 did not number the first and second paragraphs and did not include the clause found in the present 38(1): "whose function is to decide in accordance with international law such disputes as are submitted to it."

7. See, e.g., I. Brownle, Princtrles of Public International Law 1-32 (3d ed. 1979) and Restatement (Second) of Foreign Relations Law of the United States \& 1 comment c (1965).

8. See J. Brierly, The LaW of Nations 371-73 (Waldock 1963 6th ed.).

9. The Diversion of Water from the Meuse (Neth. v: Belg.), 1937 P.C.I.J. Ser. A/B, No. 70, at 73 (Hudson, J., individual opinion). 
perdu le droit d'invoquer ${ }^{10}$ the Treaty against Belgium?"11

To answer these questions, Hudson turned to "principles of equity," which "have long been considered to constitute a part of international law, and as such they have often been applied by international tribunals." 12 Recognizing the problem of distinguishing his use of equity from ex aequo et bono in article 38(2), Hudson explained:

The Court has not been expressly authorized by its Statute to apply equity as distinguished from law . . . . Article 38 of the Statute expressly directs the application of "general principles of law recognized by civilized nations," and in more than one nation principles of equity have an established place in the legal system. The Court's recognition of equity as a part of international law is in no way restricted by the special power conferred upon it "to decide a case ex aequo et bono, if the parties agree thereto ....

It must be concluded, therefore, that under Article 38 of the Statute, if not independently of that Article, the Court has some freedom to consider principles of equity as part of the international law which it must apply. ${ }^{13}$

Following the distinction between equitable principles and ex aequo et bono, Western international lawyers have usually been happier when corrections of strict law can be justified on the basis of general principles recognized in domestic systems of law. ${ }^{14}$ This not only satisfies the prescriptions of article 38 , but also apparently serves to limit the discretion of an international judge. In an international system so much based on notions of sovereignty and consent, it seems wrong to many to permit an

10. Lost the right to revoke.

11. [1937] P.C.I.J., Ser. A/B, No. 70 (Hudson, J., individual opinion), at 75.

12. Id. at 76.

13. Id. at 76-77. Dipping into the pot of general principles, Hudson then held: It would seem to be an important principle of equity that where two parties have assumed an identical or a reciprocal obligation, one party which is engaged in a continuing non-performance of that obligation should not be permitted to take advantage of a similar non-performance of that obligation by the other party. The principle finds expression in the so-called maxims of equity which exercised great influence in the creative period of the development of the Anglo-American law. Some of these maxims are, "Equality is equity;" "He who seeks equity must do equity." It is in line with such maxims that "a court of equity refuses relief to a plaintiff whose conduct in regard to the subject-matter of the litigation has been improper."

Id. at 77.

14. See supra text accompanying note 6. 
international judge to substitute his own discretion for rules more or less consented to by the parties..

The second distinction of traditional Western doctrine distinguishes equity intra legem ${ }^{16}$ praeter legem, ${ }^{17}$ and contra legem. ${ }^{18}$ As ably explained by Professor Sohn:

Application of equity infra legem, intra legem, or secondum legem simply means that a judge or an arbiter has a certain amount of discretion in interpreting the law, in clarifying obscurities and in filling minor gaps in the law. When a judge or an arbitrator applies equity in this manner, he keeps within the bounds of international law; there is no special need to authorize him explicitly to apply equity. Equity is applied praeter legem, in addition to law, whenever a tribunal is specifically empowered to decide in accordance with international law and equity. As was pointed out in an early case, this coupling of equity to law gives "greater latitude" to the arbitrator; it also permits resort to equity if the law is silent on the subject, obscure or insufficient. An arbitrator's right to give a decision on the basis of "absolute equity" seems to imply the power to act contra legem, at least to the extent of disregarding various technicalities of the law (such as the rule requiring exhaustion of local remedies)..$^{19}$

Professor Sohn concludes that there is, at least, a rough equivalence between the power to act contra legem and the power to decide ex aequo et bono, ${ }^{20}$ and thus usefully links the two types of distinctions.

As discussed above, prior to very recent times, the doctrinal debate was most active in the 1930s when hopes for international adjudication were high. An international equity tribunal was even contemplated "which would act in personam, and adjust the rights of the parties - by reference not merely to the strict law, but to the rule which is fair in all the circumstances of the particular case." ${ }^{21}$ With the failure of international peacekeeping and the outbreak of the Second World War, aspirations

15. See supra note 3.

16. Within the law.

17. Beyond the law.

18. Contrary to the law.

19. Sohn, supra note 4 , at 332 (citations omitted).

20. Id. at 332-33.

21. Holdsworth, Preface to W. Friedmann, The Contribution of English Equity To The Idea of aN InTERnational Equity Tribunal, at $\mathbf{x}$ (New Commonwealth Institute Monograph, Ser. B, No. 5, 1935). 
for international adjudication moderated and for three decades there was relatively less attention paid to the relationship between equity and international law. ${ }^{22}$

This relative quiescence was shattered in 1969 by the ruling of the I.C.J. in the North Sea Continental Shelf cases. ${ }^{23}$ There the Court dealt with the competing claims of Denmark and the Netherlands on the one hand and the Federal Republic of Germany on the other to the continental shelf off their shores. Due to the concave aspect of the German shore, if the boundaries of the Danish and Dutch portions of the continental shelf were to be delimited vis-á-vis the German share by use of the equidistance method advocated by Denmark and the Netherlands, ${ }^{24}$ then the German portion of the shelf would fold in with the German coast's concavity and the Danish and Dutch portions would be that much enlarged. ${ }^{25}$ However, the Court rejected the argument of Denmark and the Netherlands that the equidistance method of delimitation was an obligatory norm among the parties and instead ruled that:

[D]elimitation is to be effected by agreement in accordance with equitable principles, and taking into account of all the relevant circumstances, in such a way as to leave as much as possible to each Party all those parts of the continental shelf that constitute a natural prolongation of its land territory into and under the sea, without encroachment on the natural prolongation of the land territory of the other. ${ }^{28}$

The Court was very clear, as the traditional theory is clear, to distinguish equitable principles from ex aequo et bono and to explain that it was applying an equitable principle intra legem:

The Court comes next to the rule of equity. . . . Whatever the legal reasoning of a court of justice, its decisions must by definition be just, and therefore in that sense equitable. Nevertheless, when mention is made of a court dispensing justice or declaring the law, what is meant is that the decision finds its objective justification in considerations lying not outside but

22. See supra note 4. I.C.J. 4.

23. North Sea Continental Shelf Cases, (W. Ger. v. Den.; W. Ger. v. Neth.), 1969

24. The equidistance method is the "application of the principle of equidistance from the nearest points of the baselines from which the breadth of the territorial sea of each state is measured." Id. at 12.

25. See maps following 1969 I.C.J. 4, 15.

26. 1969 I.C.J. 53. 
within the rules, and in this field it is precisely a rule of law that calls for the application of equitable principles. There is consequently no question in this case of any decision ex aequo et bono, such as would not be possible under the conditions prescribed by Article 38, paragraph 2, of the Court's Statute. ${ }^{27}$

In a way, the North Sea Continental Shelf cases were an excellent "fit" for the existing equity doctrine. Not only had the I.C.J. attempted to justify its decision by reference to the traditional doctrinal distinctions, but the decision raised the very questions of the proper limits to judicial discretion that had troubled scholars and practitioners during the previous four decades. For many, the question was whether the Court had gone too far down the discretionary path. Professor Friedmann complained:

But what can scarcely be doubted is that, by rejecting the criteria laid down in the convention and other documents, the Court, in effect, was giving a decision ex aequo et bono, under the guise of interpretation. The Court applied a kind of distributive justice while denying that it was doing so. ${ }^{28}$

The North Sea Continental Shelf cases, then, evoked a new doctrinal debate about equity much in keeping with the old. Once again, international lawyers distinguished equitable principles, ex aequo et bono, equity intra legem, praetor legem, and contra legem and disagreed amongst themselves about how much discretion judges should have in modifying or supplementing strict rules of law. ${ }^{29}$

The fires of the doctrinal debate were stoked in 1977 when the Arbitral Tribunal in the Western Approaches case used eq-

27. Id. at 48.

28. Friedmann, The North Sea Continental Shelf Cases - A Critique, 64 AM. J. INT'L L. 229, 236 (1970).

29. E.g., V. Degan, L'Équite ét le drott international (1970); Von Schenck, Die Vertragliche Abgrenzung des Frestlandsockels unter der Nordsee Zwischen der Bundesrepublik Deutschland, Dänemark und den Niederlanden nach dem Urteil des Internationalen Gerichtshofes vom 20 Februar 1969, 15 JAHRBUCH PUR INTERNATIONALES REchт 370 (1971); Rothpfeffer, Equity in the North Sea Continental Shelf Cases - A Case Study in the Legal Reasoning of the International Court of Justice, 42 Nordisk Tidsskrift for International Ret og Jus Gentium 81 (1972); C. De Visscher, De L'ÉQUTTE DANS LE REGLEMENT ARBITRAL OU JUDICIARE DES LITIGES DE DROIT INTERNATIONAL PUBLIC (1972); McWhinney, Equity in International Law in EqUITY IN THE WorLd's LEgal SySTEMS: A Comparative Study 581 (R. Newman ed. 1973); Reuter, Quelques réflexions sur l'équité en droit international (part 1), 15 REVUE BELGE DE DROIT INTERNATIONAL 165 (1980). 
uitable principles in delimiting the continental shelf between France and the United Kingdom. ${ }^{30}$ The arbitration agreement between the two countries that constituted the Tribunal provided, inter alia, that:

The Court is requested to decide, in accordance with the rules of international law applicable in the matter as between the Parties, the following question:

What is the course of the boundary (or boundaries) between the portions of the continental shelf appertaining to the United Kingdom and the Channel Islands and to the French Republic, respectively, westward of 30 minutes west of the Greenwich Meridian as far as the 1,000 metre isobath? ${ }^{31}$

In its judgment, the Arbitral Tribunal followed closely in the footsteps of the I.C.J. in the North Sea cases, using the I.C.J. decision as the basis for its analysis of the proper method for delimitation. ${ }^{32}$ Accordingly, the Arbitral Tribunal rejected the notion "that delimitation of the continental shelf is . . . a question of apportionment, that is of awarding 'just and equitable' shares to each State in a common, as yet undelimited, area of shelf." Nonetheless, the Arbitral Tribunal held that "in customary law the basic principle of delimitation is that, failing agreement, the boundary must be determined in accordance with equitable principles."34 The Arbitral Tribunal, in Western Approaches, followed the I.C.J. and distinguished between the application of distributive justice and equitable principles. ${ }^{35}$ The result was substantially the same. The solution of the Arbitral Tribunal was in "remedying the disproportionality and inequitable effects produced by particular geographical configurations or features in situations where otherwise the appurtenance of roughly comparable attributions of continental shelf to each State would be indicated by the geographical facts." ${ }^{36}$ The Arbitral Tribunal, in its own words, must be responsible for "balanc-

30. Arbitration between the United Kingdom of Great Britain and Northern Ireland and the French Republic on the Delimitation of the Continental Shelf, Decisions of the Court of Arbitration, dated 30 June 1977 and 14 March 1978, reprinted in 18 INT'L LEgar. Materials 397 (1979).

31. Id. at 400 .

32. Id. at $422-27$.

33. Id. at 422 , adopting the finding of the I.C.J. in the North Sea cases.

34. Id. at 423 .

35. Id. at $426-27$.

36. Id. at 427 . 
ing equities." ${ }^{37}$ Again, doctrinal comment criticized the Court for straying too far from strict rules and for being too much an exercise in judicial discretion:

How does one know whether a court's decision is a just one? What objective foundation does it have? How does one know that the decision is not the expression of the court's subjective feelings? Such questions, characteristic of this century, have a debilitating effect on concepts such as justice and equity. ${ }^{38}$

This brief overview of the Western doctrinal legacy concerning the role of equity in international law takes us up to the middle 1970s, when equitable notions about international economic relations began to emerge. It has necessarily merged many different theories into a general description so as to explain succinctly the shared theoretical tradition of Western international lawyers. Before turning to the ways in which lawyers from such a tradition have approached the equity questions raised in the recent debate about international economic relations, ${ }^{30}$ it will be helpful to explain, again briefly, the economic and political background to claims for a new international economic order and to examine the theoretical underpinnings to Third World notions of equity in that order.

\section{Equity and the New International Economic Order}

As Western equity doctrine is rooted in the philosophy of Aristotle, ${ }^{40}$ so Third World equity doctrine derives from the economics and politics of decolonization. The newly decolonized countries of Africa and Asia, as well as their fellow less-developed states of Latin America, made slower economic progress in the 1950s and 1960s than had been expected. Because of their failure to narrow the gaps in income and standards of living in those decades between themselves and the more developed countries of the West, the developing countries found themselves even further behind by the 1970s. Whatever faith their leaders had had in the traditional economic order of trade, aid and development was accordingly weakened.1 At about the

37. Id. at 442.

38. Blecher, Equitable Delimitation of Continental Shelf, 73 AM. J. INT'L L. 60, 8788 (1979).

39. See supra text accompanying note 35 .

40. See supra text accompanying note 1 .

41. J. Bhagwati, Introduction to The New Internationhl Economic Order: The 
same time, the Oil Producing Exporting Countries (OPEC) demonstrated that some developing countries had more bargaining power than had been previously thought. ${ }^{42}$ This mix of frustrated expectations and a perception of greater power led, in no small part, to claims, beginning in the middle 1970s, for a new international economic order where global wealth would be spread more "equitably" among developing and developed countries.

This call for a new international economic order took explicit form in 1974 in three well-known United Nations General Assembly resolutions. Each contained important references to equity. The first, the "Declaration on the Establishment of New International Economic Order" proclaimed a "united determination to work urgently for" an order

based on equity, sovereign equality, interdependence, common interest and co-operation among all States, irrespective of their economic and social systems which shall correct inequalities and redress existing injustices, make it possible to eliminate the widening gap between the developed and the developing countries and ensure steadily accelerating economic and social development and peace and justice for present and future generations. $^{43}$

The Declaration asserted that the

benefits of technological progress are not shared equitably by all members of the international community. The developing countries, which constitute 70 per cent of the world's population, account for only 30 percent of the world's income. ${ }^{.4}$

As a "principle" on which to found the new international economic order, the Declaration sought

[t]he broadest co-operation of all the States members of the international community, based on equity, whereby the prevailing disparities in the world may be banished and prosperity secured for all." ${ }^{45}$

North-South Debate 5-6 (J. Bhagwati ed. 1977).

42. J. Singh, A New International Economic Order: Toward a Fair RedistribuTION OF THE WORLD'S RESOURCES 6 (1977).

43. G.A. Res. 3201 (S-VI), 6 (Special) U.N. GAOR Supp. (No. 1) 3, U.N. DOC. A/ 9556 (May 1, 1974), reprinted in 13 INT'L Legal Materials 715, 715-16 (1974).

44. Id. at 13 INT'L Legal Materials 716.

45. Id. at 717 . 
The second resolution, the "Programme of Action on the Establishment of a New International Economic Order" also included various equitable aspirations, for example:

[t]o evolve a just and equitable relationship between the prices of raw materials, primary commodities, manufactured and semi-manufactured goods exported by developing countries and the prices of raw materials, primary commodities, food, manufactured and semi-manufactured goods and capital equitment imported by them. ${ }^{46}$

and

Developed countries should make appropriate adjustments in their economies so as to facilitate the expansion and diversification of imports from developing countries and thereby permit a rational, just and equitable international division of labour. ${ }^{47}$

Furthermore, the Programme called for "an increasing and equitable participation of developing countries in the world shipping tonnage," 48 and "[f]ull and effective participation of developing countries in all phases of decision-making for the formulation of an equitable and durable monetary system,"49 and the "transfer of technology and management skills to developing countries on equitable and favorable terms."

Finally, the third of the seminal resolutions, the "Charter of Economic Rights and Duties of States," declared its purpose to be the promotion of a new international economic order based, inter alia, on "equity." The Charter, "mindful of the need to establish and maintain a just and equitable economic and social order," claimed that "relations among States" should be governed, inter alia, by the principle of "[m]utual and equitable benefit," and urged states to "co-operate in facilitating more rational and equitable international economic relations."

Such references to "equity" or to "equitable" principles, sharing, relationships, systems, terms, orders or benefits need

46. G.A. Res. 3202 (S-VI), 6 (Special) U.N. GAOR Supp. (No. 1) 5, U.N. DOC. A/ 9556 (May 1, 1974), reprinted in 13 INT'L Legal MATERIALs 720, 722 (1974).

47. Id. at 13 INT'L Legal Materials 724.

48. Id. at 725 .

49. Id.

50. Id. at 728.

51. G.A. Res. 3281 (XXIX), 29 U.N. GAOR Supp. (No. 31) 50, U.N. Doc. A/9631 (1974), reprinted in 14 INT'L LegAl Materials 251, 252 (1975).

52. Id. at 14 Int'l Legal Materials 252, 254, 256. 
not necessarily imply any legal quality; they may simply denote economic, political or moral aspirations and be devoid of legal content. Certainly such references, on their face, do not mesh well with traditional Western notions of equity as a form of corrective justice applied in specific cases by an international judge. The simple explanation for such references to equity is that they do not have any meaning in international law and at best, they were included to signal an intention to strive for the rather uncertain goal of achieving a better economic and political equilibrium between developing and developed countries.

While such an explanation may be attractive, especially in light of Western doctrine, it is inadequate in at least two ways. First, it is apparently refuted by some, though not all, of the actual references to equity made in subsequent international practice having to do with international economic relations. Second, it fails to take account of other doctrine, ascribing a legal quality to the equity references. The former point is better reserved for a subsequent part of the article ${ }^{53}$ but the latter is more properly addressed next.

\section{Equity as Distributive Justice}

Aristotle's definition of equity has already been presented..$^{54}$ However, he also presents a definition of distributive justice that seems to come closer to the meaning of equity as used by some Third World international lawyers: ${ }^{: s}$

If the persons are not equal, their [just] shares will not be equal; but this is the source of quarrels and recriminations, when equals have and are awarded unequal shares or unequals equal shares. The truth of this is further illustrated by the principle "[t]o each according to his deserts." Everyone agrees that in distributions the just share must be given on the basis of what one deserves, though not everyone would name the same criterion of deserving: democrats say it is free birth, oligarchs that it is wealth or noble birth, and aristocrats that it is excellence. ${ }^{\text {s8 }}$

It is with a belief that global wealth has been unjustly distributed that Mohammed Bedjaoui, prominent Algerian interna-

53. See infra text accompanying notes 87-97.

54. ARISTOTLE, supra note 1.

55. See infra text accompanying notes 57-64.

56. ARISTOTLE, supra note 1, bk. 5, ch. 3, at 118-19. 
tional lawyer, diplomat, and newly elected judge of the I.C.J., ${ }^{57}$ blames Europe and the United States for the poverty suffered by the Third World, ${ }^{58}$ and calls for a new international law emphasizing a "principle of equity." $\mathrm{He}$ argues:

This international law of participation, genuinely all-embracing and founded on solidarity and co-operation, must give great prominence to the principle of equity (which corrects inequalities) rather than to the principle of equality. In doing so, it must keep the objective in view, which consists of reducing and, if possible, even of eradicating the gap that exists between a minority of rich nations and a majority of poor nations. There is no doubt at all that it is a far-reaching legal revolution to have given international law this task of fostering a policy of development and to have made this an "international legal duty" for the rich States and a "subjective international right" for the developing countries. ${ }^{58}$

At first glance, this notion of equity is very different from that understood in traditional Western doctrine. It makes no mention of the discretion of judges, and does not distinguish equitable principles in article $38(1)$ (c) from ex aequo et bono in article 38(2). It does not suggest flexible correction of strict rules of law, whether intra, praeter, or contra legem, but rather suggests a norm correcting existing distributions of wealth. This view of equity might be recognized as a form of distributive justice.

Such a recognition is made by another Third World international lawyer, Inamul Haq. Haq submits that " $[t]$ he case for obligatory transfer of resources [from developed to developing countries] rests ultimately on the principle of distributive justice and economic equity in the global context,"60 and believes that international law is, at present, an "emerging law of transnational welfare and need based entitlement."

It can, of course, be argued that views such as those of Bedjaoui and Haq are simply wide of the mark, and that equity

57. I.C.J. Communique \# 82/8, April 29, 1982.

58. M. Bedjaout, Towards a New International Economic Order, 119 (1979) [hereinafter cited as BedjAour]. See also Janis, Book Review, 5 B.C. INT'L \& Comp. L. REv. 355 (1982).

59. BEDJAOUI, supra note 58, at 127.

60. Haq, From Charity to Obligation: A Third World Perspective on Concessional Resource Transfers, 14 TEx. INT'L L.J. 389, 406 (1979).

61. Id. at 423 (chart). 
in international law has nothing to do with distributive justice. However, if one reads the materials that have issued from the various United Nations meetings and conferences dealing with a new international economic order, one notes that in some cases the texts themselves appear to display the same preference for treating equity as a matter of distributive justice.

For example, "The Set of Multilaterally Agreed Equitable Principles and Rules for the Control of Restrictive Business Practices," adopted on April 22, 1980 at the United Nations Conference on Restrictive Business Practices declared "that restrictive business practices can adversely affect international trade, particularly that of developing countries, and the economic development of these countries" affirmed that its objective is to contribute to the "development and improvement of international economic relations on a just and equitable basis." What is the sense of "equitable," a notion finding its way into the document's title as well as its preamble? Under a subsection entitled "Preferential or differential treatment for developing countries," it is stated:

In order to ensure the equitable application of the Set of Principles and Rules, States, particularly of developed countries, should take into account in their control of restrictive business practices the development, financial and trade needs of developing countries, in particular the least developed countries, for the purposes especially of developing countries in:

(a) promoting the establishment or development of domestic industries and the economic development of other sectors of the economy; and

(b) encouraging their economic development through regional or global arrangements among developing countries. ${ }^{63}$

Two Western participants in the negotiations leading to the drafting of the Set of Equitable Principles and Rules observed that the Group of 77's "favorite modifier was 'equitable,' with its aura of egalitarianism." One wonders if this is a proper characterization of the Third World's meaning of "equitable." The very heading, "Preferential or differential treatment for developing countries," demonstrates the anti-egalitarian aspect of the

62. U.N. Doc. TD/RBP/CONF./10 (May 2, 1980), reprinted in 19 INT'L LEGAL Materials 813, 814 (1980).

63. Id. at 817 .

64. Atkeson \& Gill, The UNCTAD Restrictive Business Practices Code: A Step in the North-South Dialogue, 15 INT'L LAw. 1, 6 at n.11 (1981). 
Third World's interpretation of "equitable principles." "Equitable" in this document seems to mean what Bedjaoui and Haq would have it mean: a form of distributive justice, aimed to meet the needs of the developing countries.

There are, however, many other references to equity or to things equitable in recent international practice that less clearly indicate the accuracy of such a distributive justice explanation of the meaning of equity. Some such references are, in fact, ambiguous and can be read differently depending on one's perceptions of the meaning of the term. Before turning to some examples, let us return to Western doctrine to see how some Western international lawyers have dealt with equity in its recent appearances in practice.

\section{Equity as Discretionary Justice}

Third World international lawyers nowadays see equity notions as emerging from perceived economic and political injustices in the global distribution of wealth and power. Western international lawyers, however, have generally remained true to their tradition, viewing equity as a flexible corrective function in specific cases not well-handled by strict universal rules. It is submitted that this traditional perception of equity is best characterized as discretionary justice. This may be seen in two recent commentaries by noted Western international lawyers dealing, inter alia, with the use of equity notions in international relations.

The first, by Ian Brownlie, considers the international legal status of natural resources, and in a section entitled "The Relevance of Equitable Principles" considers equity because "at first sight equity provides a major source of principles of distribution." appear as a natural part of legal and therefore of judicial reasoning," ${ }^{66}$ Brownlie describes and criticizes the recent maritime decisions employing equitable principles:

The principles laid down in the North Sea Continental Shelf cases as applied and elaborated upon by the distinguished Court of Arbitration in the Western Approaches Arbitration

65. Brownlie, Legal Status of Natural Resources in International Law (Some Aspects), 162 Hague Academy, Recuenl des Cours 245, 287 (1979) [hereinafter cited as Brownlie, Legal Status].

66. Id. 
lead to a striking result. There is no longer even a presumption in favor of equidistance in the case of adjacent areas of shelf, and the actual delimitation produced in the Western Approaches Arbitration on the basis of "equitable principles" suggests that in this context such principles amount to no more than a bundle of highly impressionistic ideas about the "distorting" effect, so-called, of islands. Employed in this way "equitable principles" become merely faint indications of the reasoning, or of the unreasoned premises, on which judicial discretion has been exercised and may be exercised in other cases. The point is a simple one: with little or no clear content a direction to apply equitable principles is a conferment of a general discretionary power upon the decision-making body. ${ }^{67}$

It is on this basis that Brownlie altogether rejects the utility of equity for difficult problems facing international law, implicitly including those of international economic relations:

The material concerning equitable principles in contemporary international law seems to justify two general observations. First, the role of equitable principles is limited to particular contexts and to the occasional necessities of legal and judicial reasoning. Secondly, the most significant role of "equitable principles" is to confer a wider discretion on tribunals and this also in specific contexts. Whatever the particular and interstitial significance of equity in the law of nations, as a general reservoir of ideas and solutions for sophisticated problems it offers little but disappointment. ${ }^{68}$

For present purposes, Brownlie's hostility towards the role of equity in international law is less important than his interpretation of equity's role largely to be conferring "a wider discretion on tribunals." ${ }^{\circ}$ Although in the work quoted above he does not refer in great detail to Western equity doctrine, his larger treatise shows a reliance on such doctrine, the greater part of the equity section there being devoted to aspects of the distinction between equitable principles and the principle of ex aequo et bono. ${ }^{70}$ What is curious, if not altogether surprising, is that Brownlie should assume that the doctrinal analysis traditionally employed to describe and critique problems relating to judicial discretion, should be used in describing and criticizing equitable

67. Id.

68. Id.

69. Id.

70. I. Brownlie, Principles of Public International Law 27-29 (3d ed. 1979). 
claims for a new international economic order. It should be pointed out that later in the quoted work, Brownlie does address "principles of preference as agents of distributive justice working in favour of developing States," "11 but does so without reference to the potential for the application of equity and largely to show that such preferences run up against a very real problem if one does not or can not adequately define what is meant by a "developing state."72

The second important Western comment is by Elihu Lauterpacht. Although Lauterpacht is more favorably disposed towards the use of equity than Brownlie, both Westerners agree that equity in international law is a form of discretionary justice. Lauterpacht distinguishes his use of equity from that where the principle of equity applied has

specific content which does not vary according to the factual context in which it falls to be applied. With this kind of 'principle of equity' or 'equity' we are not here concerned. Instead we are occupied with something much vaguer and more relative, more closely comparable with the concept of ex aequo et bono as it appears in Article 38(2) of the Statute of the International Court of Justice. ${ }^{73}$

Lauterpacht points out that "the concept of equity is increasingly being employed as an element in the description of specific international legal relationships." " As examples, he cites cases from the 1930s, the recent cases involving maritime delimitation and some instances from recent treaty or draft treaty practice. ${ }^{75}$ $\mathrm{He}$ then argued "that the idea of equity is often introduced without sufficient elaboration of its content," "re relying not on the argument made above about the difference between equity as distributive and as discretionary justice, but primarily on the argument that the Court in the North Sea and Icelandic Fisheries cases and the arbitral tribunal in Western Approaches inad-

71. Brownlie, Legal Status, supra note 65, at 301.

72. Id. at $301-05$.

73. Lauterpacht, Equity, Evasion, Equivocation and Evolution in International Law, Proceedings and Committee Reports of the Am. Branch of the Int'l L. Ass'N (1977-78) 33, 33-34.

74. Id. at 33 .

75. Id. at 34-39. Lauterpacht notes that the word "equity" appears in at least six different places in the Informal Composite Negotiating Text of the Law of the Sea. Id. at 37. References to equity are also found in articles prepared by the International Law Commission and in the Final Act of the Helsinki Conference of 1975. Id. at 38-39.

76. Id. at 39 . 
equately explain the bases for their decisions. ${ }^{77}$

However, Lauterpacht, unlike Brownlie, says that "although recourse to equity may be made the subject of criticism, it is not necessarily a bad thing." 78 By this he means that recourse to equity may be had to "provide the essential link that enables the parties to have recourse to compulsory judicial settlement."79 Lauterpacht puts aside the old distinction between equity as a general principle and ex aequo et bono, but remains true to the tradition of viewing equity in international law as a form of discretionary justice:

It must be appreciated that whether we are discussing a decision ex aequo et bono (in traditional terms, a decision completely outside the law) or whether we are considering equity in the new sense of 'equity within the law,' we are talking about a situation in which the court is being asked to apply a subjective or discretionary element. ${ }^{80}$

Lauterpacht argues that if judges or arbiters are going to rely on such subjective or discretionary elements, they should give the parties an opportunity to argue the points involved before the court. ${ }^{81}$

Finally, and most interestingly for our purposes, Lauterpacht returns to the appearance of equity and equitable principles in recent international practice. He fits these references into his framework of equity as discretionary justice:

If political factors in any given multilateral negotiation exclude the formulation of precise rules and lead to what is substantially a prevaricating solution expressed in terms of 'equity' (and this is likely to happen more frequently as further multilateral treaties of a sensitive economic character are concluded), then States must be prepared to accept two things. First, in those situations in which treaty or customary international law requires the parties to seek an agreement on the basis of 'equity' or 'equitable principles,' States will need to be genuinely ready to negotiate seriously and in good faith to implement the obligation thus resting upon them . . . . Secondly, States will need to accept that when negotiations have endured beyond the reasonably extended patience of one party, then

77. Id. at $39-43$.

78. Id. at 43.

79. Id. at 44 .

80. Id. at 45 .

81. Id. at $45-46$. 
that party should be entitled to introduce into the process the assistance of a third person. This assistance need not necessarily take the form of binding third-party settlement. It could take the form of a conciliation - a process which is inherently not binding. It should, however, be an obligatory process of conciliation which can be initiated by one party alone without further consent by the other. ${ }^{82}$

Like Brownlie, who believes that "a direction to apply equitable principles is a conferment of a general discretionary power upon the decision-making body,"83 Lauterpacht thus appears to understand references to equity and equitable principles very differently than do Bedjaoui and Haq. Where Badjaoui sees equity as a principle designed to "eradicat[e] the gap that exists between a minority of rich nations and a majority of poor nations" economic equity in the global context," ${ }^{85}$ Lauterpacht reads equity as part of a "move in the direction of a more flexible and responsive international law." ${ }^{86}$ The question now before us is how well or how poorly these contrasting doctrines work in explaining recent international practice.

\section{Equity in Recent International Practice}

The equity references in the three 1974 General Assembly Resolutions calling for a new international economic order, ${ }^{87}$ as well as those in "The Set of Multilaterally Agreed Equitable Principles and Rules for the Control of Restrictive Business Practices," have already been examined. ${ }^{88}$ In those instances, the equity references, insofar as they have any meaning, denote a form of distributive justice, which would meet the needs of the developing countries, rather than a form of discretionary justice, which permits more flexible resolution of disputes. Most equity references, however, cannot so clearly be put into the distributive justice camp.

For example, article 11(7) of the United Nations' 1979 "Agreement Governing the Activities of States on the Moon and

\footnotetext{
82. Id. at 46-47.

83. Brownlie, Legal Status, supra note 65, at 287.

84. BEDJAOUI, supra note 58, at 127.

85. Haq, supra note 60 .

86. Lauterpacht, supra note 73 , at 46 .

87. See supra text accompanying notes 43-52.

88. See supra text accompanying notes $62-63$.
} 
Other Celestial Bodies" reads, in part:

The main purpose of the international regime to be established shall include:

(d) An equitable sharing by all States Parties in the benefits derived from those resources, whereby the interests and needs of the developing countries, as well as the efforts of those countries which have contributed either directly or indirectly to the exploration of the moon, shall be given special consideration. ${ }^{89}$

This provision for "equitable sharing" can be read cogently in either a distributive or a discretionary justice way. If equity is understood to mean meeting the needs of the developing countries, the provision says that although the developing countries may not have "contributed either directly or indirectly to the exploration of the moon," their "interests and needs" "shall be given special consideration" in the "sharing" of the benefits derived from moon resources, i.e., a share in proportion to their needs rather than a share in proportion to their contribution. However, if one understands equity to mean a flexible as opposed to a strict rule, the provision indicates that the sharing of benefits will be negotiated at another time, that considerations to be taken into account may include, inter alia, interests and needs of developing countries and contributions of exploring countries, and further, that the parties commit themselves to good faith negotiation and, if such fails, to third party settlement.

Although one might examine many other problematic references to equity in recent international practice,$^{90}$ it will be especially instructive to concentrate here on the equity provisions in

89. U.N. Doc. A/34/664 (Nov. 12, 1979), reprinted in 18 INT'z Legal Materials 1434, 1438 (1979).

90. See, e.g., Lima Declaration and Plan of Action on Industrial Development and Co-operation, Mar. 26, 1975, arts. 12, 58(d), 61(j), U.N. Doc. ID/B/155/Add. 1 (Apr. 19, 1975), reprinted in 14 INT'L Legal Materials 826, 833, 840 (1975); Restructuring of the Economic and Social Sectors of the United Nations System, Dec. 20, 1977, G.A. Res. 32/ 197, U.N. Doc. A/Res/32/197 (Jan. 9, 1978), arts. 35, 36, reprinted in 17 INT'L LegAL Materials 235, 243 (1978); Treaty for Amazonian Cooperation, done at Brasilia, art. XII, Jul. 3, 1978, 17 INT'L Legal Materials 1045, 1049 (1978); Draft International Code of Conduct on the Transfer of Technology, May 6, 1980, U.N. DOC. TD/CODE TOT/25 (June 2, 1980), reprinted in 19 INT'L Legal Materials 773, 777, 779 (1980); Agreement Establishing the OPEC Fund for International Development, as revised on May 27, 1980, $\S 5.05$, reprinted in 19 INT'L Legal Materials 880, 882-83 (1980) and Treaty of Montevideo Establishing the Latin American Integration Association, Done at Montevideo Aug. 12, 1980, art. 1, reprinted in 20 INT'L Legal Materiats 672, 673 (1981). 
the 1982 "United Nations Convention on the Law of the Sea" (hereinafter referred to as UNCLOS). ${ }^{91}$ Not only does the Convention represent a particularly important step for the developing countries in molding a new international economic order, but the equity provisions in the Convention display a considerable and confusing degree of variety.

The references to equity in the Convention can, and in some instances must, be understood differently depending upon the reader's use of the two existing equity theories. The quest for " $a$ just and equitable international economic order," the preamble, seems to echo the equity language of the 1974 new international economic order resolutions ${ }^{93}$ calling for a form of distributive justice. The references to "equitable principles" in the delimitation provisions ${ }^{94}$ are best understood in the context of negotiated settlements and flexible decision-making associated with traditional Western notions of equity as a form of discretionary justice. The mention of "equitable geographical distribution"9s probably refers to a form of proportionality based on geography and may be meant, interestingly, to limit rather than broaden the discretion of the Council. The other and more numerous references to equity ${ }^{98}$ must remain, if we rely on the

91. United Nations Convention on the Law of the Sea, Oct. 7, 1982, U.N. Doc. A/ CONF. 62/122.

92. The preamble to the Convention refers to equity similarly to other documentation calling for distributive justice and a new international economic order. It seeks the realization of a just and equitable international economic order which would take into account the interests and needs of developing countries, whether coastal or land-locked. Id. preamble.

93. See supra text accompanying notes 43-52.

94. There are two provisions that seem to be in keeping with the cases using equitable principles in the delimitation of maritime areas. Article 74 concerning "[d]elimitation of the exclusive economic zone between States with opposite or adjacent coasts," and article 83 dealing with "[d]elimitation of the continental shelf between States with opposite or adjacent coasts" provide that delimitation "shall be effected by agreement on the basis of international law, as referred to in article 38 of the Statute of the International Court of Justice, in order to achieve an equitable soluition." Id. art. 74 (1), art. 83 (1).

95. Article 163, "Organs of the Council," contains an equity reference that apparently means geographical proportionality: "In the election of members of the Commissions, due account shall be taken of the need for equitable geographical distribution and the representation of special interests." Id. art. 163(4).

96. The most numerous of the equity provisions in the Convention are not clearly drawn from either the new international economic order debate or from the maritime delimitation cases nor do they have another, more specifically textual, meaning. Article 59 concerns the "[b]asis for the resolution of conflicts regarding the attribution of rights and jurisdiction in the exclusive economic zone:"

In cases where this Convention does not attribute rights or jurisdiction to

the coastal State or to other States within the exclusive economic zone, and a 
two existing theories, objectively uncertain. Such provisions can, like the equity provision in the Moon Treaty, be read to mean either a share for developing countries based on their needs or a commitment to a flexible result to be subsequently negotiated in good faith. Given the importance of the Convention and the many other references to equity in recent international practice, ${ }^{97}$ an attempt should be made to do better than reach such an uncertain result. With all due respect to (and to a considerable extent drawing upon) the two theories of equity already considered, a third theory to account for the meaning of equity in international law, especially with respect to the practice concerning international economic relations, is set forth below.

conflict arises between the interests of the coastal State and any other State or States, the conflict should be resolved on the basis of equity and in the light of all the relevant circumstances, taking into account the respective importance of the interests involved to the parties as well as to the international community as a whole.

Id. art. 59. Article 69 concerns "[r]ight of land-locked States:"

1. Land-locked States shall have the right to participate, on an equitable basis, in the exploitation of an appropriate part of the surplus of the living resources of the exclusive economic zones of coastal States of the same subregion or region, taking into account the relevant economic and geographical circumstances of all the States concerned and in conformity with the provisions of this article and of articles 61 and 62 .

....

3. When the harvesting capacity of a coastal State approaches a point which would enable it to harvest the entire allowable catch of the living resources in its exclusive economic zone, the coastal State and other States concerned shall cooperate in the establishment of equitable arrangements on a bilateral, subregional or regional basis to allow for participation of developing land-locked States of the same subregion or region in the exploitation of the living resources of the exclusive economic zones of coastal States of the subregion or region, as may be appropriate in the circumstances and on terms satisfactory to all parties.

Id. art. 69(1,3). Provisions comparable to those in article 69 exist in article 70 for "[r]ight of geographically disadvantaged states." Id. art. 140(2).

Article 140 concerning "[b]enefit of Mankind" provides: "The Authority shall provide for the equitable sharing of financial and other economic benefits derived from activities in the Area through any appropriate mechanism, on a non-discriminatory basis ... ." Id. art. 140(2). A comparable provision calling for the "equitable exploitation" of the seabed "for the benefit of all countries, especially the developing States," exists in article 155(2) concerning "The Review Conference." Id. art. 155(2). Finally, article 266(3) concerning "[p]romotion of the development and transfer of marine technology" reads: "States shall endeavour to foster favourable economic and legal conditions for the transfer of marine technology for the benefit of all parties concerned on an equitable basis." Id. art. 266(3).

97. See, e.g., citations in note 90 , supra. 


\section{Equity as Measured Justice}

Having looked to the conflicts between perceptions of equity as distributive justice and as discretionary justice, the remaining task is to elaborate upon a third perception of the role of equity in international law, which tends to bridge the gap between the two existing schools. It is hoped that this new theory will facilitate a clearer and more consistent understanding of what equity means in the practice concerning international economic relations.

This can best be done by beginning with Western doctrine and breaking up its analysis of the role of equity in international law into two more or less discrete aspects. First is the aspect most often discussed: the degree to which international judges should be free to disregard or supplement strict rules. Really this aspect is a "false" equity enquiry; what it concerns is the role not of equity, but of judges in international law. Given the decentralized international political system and the great respect shown in theory for state sovereignty ${ }^{88}$ how can a judge have the power to go beyond the rules of law theoretically already consented to by the parties either in treaty, custom or municipal practice? However far one decides a judge or other decision-maker can or should go beyond strict rules of law, assuming that the judge can exercise some discretion, one then faces the "true" equity question: If the judge may go beyond strict rules, what other standards shall he use in rendering his decision? This is an equity problem common to all legal systems and is not peculiar to international law. ${ }^{99}$

It is at this point that Western equity theory most nearly approximates Third World theory. Where the discretionary justice school is asking what standards outside of strict legal rules may or should be applied by a judge, the distributive justice

98. See, e.g., C. De Visscher, Theory and Reality in Public International Law 3. 68 (P. Corbett trans. 1968).

99. One can take a narrower view of the role of equity generally. Newman, for example, writes:

The word "equity" and its various synonyms are used in two widely different senses; in the general sense of what is fair and just, which is the objective of all law, and in the specific sense of an element of law which introduces distinctive ethical values into the legal norms.

Newman, Introduction, Equity in tHe WorLd's Legal Systems: A Comparative Study, 15 (R. Newman ed. 1973). While I agree that equity can introduce ethical values into law, I would say that it can also introduce other extra-legal standards not properly identified as "ethical." 
school proposes that there should be a norm calling for the distribution of wealth based on need. Advocates of equity as discretionary justice may not accept this as a proper standard, but they nonetheless should be able to recognize need as a possible, even if unacceptable, equitable criterion.

What to term this almost-meeting point? It might be thought of as a theory of equity as measured or proportionate justice. Aristotle, in his discussion of distributive justice, talks about the importance of proportion:

The just, then, in this sense, is the proportional, and the unjust is what violates the proportion. Consequently, the unjust admits of a more and a less, and that is what takes place in actual fact; a man who acts unjustly has more than his share of good, and a man who is treated unjustly has less. ${ }^{100}$

Both the schools of distributive justice and discretionary justice emphasize such problems of proportion. This is easily noticed in theories of distributive justice because they are explicitly concerned with a proportionate distribution of wealth among different countries. ${ }^{101}$ In theories of discretionary justice, proportion is considered more subtly, because it is only after the question relating to the grant of discretion to the judge is answered that these theories address themselves to the substance of standards used by judges in their discretion. Note how Brownlie and Lauterpacht criticize the arbiters in Western Approaches for using equitable principles as "no more than a highly impressionistic idea"102 and giving "no explanation" for "how the various factors mentioned by the tribunal actually led it to [its] conclusions." 103 One could take these criticisms to mean that Brownlie and Lauterpacht are dissatisfied with the opportunity made available to themselves and to others to understand the standards incorporated by equity that were used to decide the specific case. Here Western doctrine has moved on to the second, more purely "equity," question of the standards to be used by the judge once he has moved beyond the application of strict rules. It is a process that calls for the judge to measure the specific case against extra-legal standards, e.g., ethical, economic and geographical. The objections of Brownlie and Lauterpacht to Western Approaches

100. ARISTOTLE, supra note 1 , at 120.

101. See supra text accompanying notes 58-61.

102. Brownlie, Legal Status, supra note 65, at 287.

103. Lauterpacht, supra note 73 , at 43 . 
seem to be that the arbiters failed to make their equitable standards explicit and thus provided no good idea of their concept of equity.

If we view equity as measured justice, where the result is fairly proportional to some non-legal standards, what is the result for those difficult equity references in recent international practice? With regard to the Moon Treaty, ${ }^{104}$ using the measured justice theory, an "equitable sharing" in the Treaty means that the sharing of the benefits must be fairly proportional to certain extra-legal standards, including the needs of developing countries and the extent to which countries have contributed to the exploration of the moon. While it might be appropriate for the international regime to use other standards as well, it would be inappropriate for the international regime not to use, at least in part, these two standards in making its decisions. Importantly, it is neither presumed that the equity provision aspired to eradicate the economic gap between rich and poor countries, nor insisted that the parties have committed themselves, in case of disagreement, to third party dispute settlement.

The more difficult test is the Convention on the Law of the Sea. ${ }^{105}$ As explained above, ${ }^{106}$ some of the equity references, for example, that in the preamble to " $a$ just and equitable international economic order" and those in articles 74 and 83 to maritime delimitation, are probably best understood using, respectively, the distributive justice and discretionary justice doctrines. For the rest, however, the measured justice theory may help. Easiest of all is article 163 concerning "equitable geographical distribution" where the extra-legal standard to be used is made explicit, that is, a standard based on geographical criteria.

But how is one to analyze the problem clauses, such as article 59's reference to a "basis of equity," article 69's and 70's "equitable basis" and "equitable arrangements," article 140's "equitable sharing," article 155's "equitable exploration," and article 266's "equitable basis," where no such explicit standard exists? Unlike the reference in the preamble and those in articles 74 and 83 , these illustrations do not have a contextual appearance clearly calling for one or the other of the distributive or discre-

104. See supra text accompanying note 89.

105. See supra notes $91-96$ and accompanying text.

106. See supra text following note 97 . 
tionary theories. As was argued above, either theory could explain the references, but this would undoubtedly lead to conflict.

The solution, it is submitted, is to begin by rejecting the absolutist element of each existing theory, and next, to take a principle from each to create a new theory. First, from Western doctrine, it is necessary to understand that there is no fixed rule, and instead, as is usual with equity, each particular case is to be settled with reference to its own special characteristics. Second, from Third World doctrine, realize that in so settling each case, the needs of the developing countries, as set out in the preamble, are to be taken into account as one, though not necessarily the only, extra-legal measure to be used in rendering decisions. This might be a workable compromise, drawing on both doctrines and making sense in terms of each.

\section{CoNCLUSION}

It is more readily apparent that the present meaning of equity in international law is ambiguous than that the new measured justice theory, as suggested above, is an adequate compromise between the prevailing theories of Western discretionary justice and Third World distributive justice. It may be, in fact, that there are just too many differences concerning the term and that no single theory can account for the term equity. This result, while unfortunate, may be indicative of a general problem of international law.

Given the different backgrounds and understandings of international lawyers drawn from many societies, there may be, at times, more actual disagreement than would be apparent on the surface. With equity, for example, despite the term's appearance in so much of international practice, the term may mean not too little, but rather, too much, taking on different meanings for different observers. Where there is apparent agreement, there may be implicit ambiguity. However inadequate the new theory elaborated above may be, it is an attempt to bridge an actual disagreement in a fashion perhaps acceptable to both sides.

On the larger problem of understanding international law from differing national, societal and doctrinal perspectives, the answer must be to devote more effort to the study of international law as a part of comparative law. It needs to be recognized that a single, universally understood perception of international law does not always exist. There may be, in fact, different perceptions, each perhaps valid in its own right, which should be fit 
together, if possible, with the others. Although there are some very useful beginnings in the comparative study of internation ${ }^{3}$ law, ${ }^{107}$ there is far less attention paid to the subject than is warranted. It is a matter well suited to academic analysis, calling for the examination and reconciliation of differing doctrines. Hopefully, this study of the ambiguity of equity is a step in the right direction.

107. See, e.g., International Law in Comparative Perspective (W.E. Butler ed. 1980). 